\title{
Glomerular and Tubular Functions in Children and Adults with Transfusion-Dependent Thalassemia
}

\author{
Transfüzyona Bağımlı Çocuk ve Erişkin Talasemi Hastalarında Glomerüler ve Tubuler Böbrek \\ Fonksiyonları
}

\author{
(D) Agageldi Annayev ${ }^{1}$, (D) Zeynep Karakaş ${ }^{1}$, (D) Serap Karaman ${ }^{1}$, (D) Altan Yalçıner ${ }^{2}$, (D) Alev Yılmaz ${ }^{3}$, (D) Sevinç Emre ${ }^{3}$ \\ ${ }^{1}$ Istanbul University Istanbul Faculty of Medicine, Department of Pediatric Hematology and Oncology, Istanbul, Turkey \\ ${ }^{2}$ Düzen Laboratories, Istanbul, Turkey \\ ${ }^{3}$ istanbul University Istanbul Faculty of Medicine, Department of Pediatric Nephrology, Istanbul, Turkey
}

\section{Abstract}

This study aimed at assessing renal functions in patients with transfusion-dependent thalassemia (TDT). Fifty patients and 30 controls were enrolled in this prospective study. Serum levels of electrolytes and albumin were measured by a spectrophotometer. Serum levels of cystatin- $C$ and urinary levels of $\beta 2$-microglobulin were measured by nephelometric method. Thirty-eight patients were receiving deferasirox and 8 were on deferiprone. Serum electrolytes and albumin levels of the patients were found to be within normal ranges. Urinary $\beta 2$-microglobulin and serum cystatin-C levels were significantly higher in patients than controls. They did not significantly differ between the subgroup of patients on deferiprone and the control group, whereas they were found to be higher in patients using deferasirox compared to controls. Urinary $\beta 2$-microglobulin levels significantly increased in patients who were receiving high-dose deferasirox compared to those who were receiving a daily dose of $15-20 \mathrm{mg} / \mathrm{kg}$ or controls. Subclinical renal injury may be present in TDT patients.

Keywords: Thalassemia, Tubulopathy, Glomerulopathy, $\beta 2-$ Microglobulin, Cystatin

\begin{abstract}
Öz
$\mathrm{Bu}$ çalışmada transfüzyona bağımlı talasemi (TBT) hastalarında böbrek fonksiyonlarının değerlendirilmesi amaçlanmıştır. Prospektif çalışmaya, 50 TBT ve 30 kontrol grubu dahil edildi. Serum elektrolitleri ve albumin düzeyleri spektrofotometre ile ölçüldü. Serum sistatin-C ve idrar $\beta 2$-mikroglobülin düzeyleri nefelometrik yöntemle ölçüldü. Otuz sekiz hasta deferasiroks, 8 hasta deferipron alıyordu. Hastaların serum elektrolitleri ve albumin düzeyleri normal sınırlardaydı. İdrar $\beta 2$ mikroglobulin ve serum sistatin-C düzeyleri hasta grubunda kontrol grubundakilere göre anlamlı derecede yüksekti. Serum Cys- $\mathrm{C}$ ve idrar $\beta 2$-mikroglobulin düzeyleri, deferipron kullananlar ve kontrol grubu arasında anlamlı farklılık göstermezken, deferasiroks kullananlarda kontrol grubuna göre daha yüksek bulundu. İdrar $\beta 2$ mikroglobulin düzeyleri, yüksek doz deferasiroks alan hastalarda, $15-20 \mathrm{mg} / \mathrm{kg} /$ gün deferasiroks alanlara veya kontrol grubuna göre anlamlı şekilde artmıştı. Transfüzyona bağımlı talasemi hastalarında subklinik olarak renal hasar mevcut olabilir.
\end{abstract}

Anahtar Sözcükler: Talasemi, Tubulopati, Glomerulopati, $\beta 2$ Mikroglobulin, Sistatin C

\section{Introduction}

Iron accumulation may lead to renal damage in transfusiondependent thalassemia (TDT) $[1,2]$. Cystatin C (Cys-C), a small molecular weight protein, is filtered from the glomeruli, reabsorbed from the tubular cells, and metabolized from the kidneys. It is a good marker for glomerular filtration rate (GFR). $\beta 2$-Microglobulin ( $\beta 2 \mathrm{MG})$, a single-chain, low-molecular-weight polypeptide, is filtered by the glomeruli, then reabsorbed and catabolized in the proximal tubular cells. Increased urinary excretion of $\beta 2 \mathrm{MG}$ may demonstrate tubular dysfunction. Our study assessed kidney function in patients with TDT using serum Cys-C (SCys-C) and urinary $\beta 2 \mathrm{MG}(\mathrm{U} \beta 2 \mathrm{MG})$ measurements in addition to routine tests, as well as the utility of these markers as indicators for early glomerulopathy and tubulopathy.

\section{Materials and Methods}

Fifty patients with TDT, 25 under and 25 above the age of 18 , have been followed since their childhood by the Thalassemia

๑Copyright 2018 by Turkish Society of Hematology

Turkish Journal of Hematology, Published by Galenos Publishing House

口.

Faculty of Medicine, Department of Pediatric Hematology and Oncology, İstanbul, Turkey

Phone : +90 5334378130

E-mail : drkaramans@yahoo.com ORCID-ID: orcid.org/0000-0002-7428-3897 
Center at the İstanbul Faculty of Medicine of İstanbul University. Twenty-two patients were male and 28 were female. The mean age was $18.4 \pm 11.8$ years (range: $2-45$ ). Thirty age- and sexmatched subjects were included in the control group. Ethical approval was granted by the institutional review board and patient consent was obtained.

Serum electrolytes, urine calcium/creatinine (uCa/Cr) and fractional excretion of sodium (FENa), GFR, proteinuria, serum $\mathrm{Cr}$, and albumin levels were measured and were compared to their reference ranges in the patient group. SCys-C and U $\beta 2 M G$ levels in the patient group were compared to those of the controls and potential correlations between SCys-C or U $\beta 2 \mathrm{MG}$ levels and the severity of anemia, ferritin levels, and chelation therapy were also evaluated. Blood samples collected to measure SCys-C were cold-centrifuged at $4000 \mathrm{rpm}$ for $10 \mathrm{~min}$. A photometric analysis of serum albumin, urea, $\mathrm{Cr}$, uric acid, and electrolyte levels was conducted. Ferritin levels were measured by the electrochemiluminescent immunoassay method. SCys-C and U $\beta 2 \mathrm{MG}$ levels were measured by nephelometry.

Statistical analysis was done using SPSS 17.0.

\section{Results}

No significant differences were found between the patients and controls in terms of age or sex ( $p>0.05)$. Demographic and clinical characteristics of the patients are summarized in Table 1. In the patients, serum $\mathrm{Na}, \mathrm{K}, \mathrm{Ca}, \mathrm{P}, \mathrm{Mg}$, urea, $\mathrm{Cr}$, and albumin were within normal limits. None of the patients had proteinuria. The mean $\mathrm{uCa} / \mathrm{Cr}$ ratio was found to be higher than the normal level. Estimated GFR was elevated in the patient group (Table 2). SCys-C and U $\beta 2 M G$ levels were higher in patients than controls $(p=0.001, p=0.010)$ (Table 3$)$. SCys- $C$ was increased with age $(r=0.376 ; p=0.007)$. No correlations were found between U $\beta 2 M G$ levels and age $(r=-0.186, p=0.217)$.

Renal dysfunction was detected in 30 out of 50 patients. FENa levels were increased in 8 patients, while U $32 \mathrm{MG}$ and SCys-C levels were increased in 9 and 25 patients, respectively. In our study, renal involvement was observed in 54\% of the patients under the age of 18 and 64\% of the patients above the age of 18. No correlations were observed between the mean SCys-C and U $\beta 2 M G$ levels and pretransfusion hemoglobin and iron load ( $p>0.05$ ) (Figures 1 and 2). No correlations were found between SCys-C and ferritin levels. The assessment of the correlations between the U $\beta 2 \mathrm{MG}$ and ferritin levels in patients revealed that U $\beta 2 \mathrm{MG}$ levels were greater than in the controls, particularly in those who had a ferritin level of $<500 \mathrm{ng} / \mathrm{mL}$ or $>1000 \mathrm{ng} /$ $\mathrm{mL}(\mathrm{p}=0.001)$. Although U $\beta 2 \mathrm{MG}$ levels were slightly elevated in the patients who had ferritin levels between 500 and $1000 \mathrm{ng} /$ $\mathrm{mL}$, the difference between the patients and controls was not statistically significant ( $p>0.05)$.
The distribution of patients by their chelation therapy was as follows: 38 patients (75.5\%) were on deferasirox (DFX); 8 $(16.3 \%)$ were on deferiprone (DFP). Among the patients who were on DFX, 11 (31\%) were receiving a dose of $15-20 \mathrm{mg} / \mathrm{kg} /$ day, 13 (33\%) were receiving a dose of 20-30 mg/ $\mathrm{kg} / \mathrm{day}$, and 14 (36\%) were receiving a dose of $30-40 \mathrm{mg} / \mathrm{kg} /$ day. When SCys-C concentrations were categorized by iron chelation therapy, there were no differences between the patients who were on DFP and the controls, while significant differences were found between

\begin{tabular}{|c|c|c|c|}
\hline \multicolumn{3}{|c|}{$\begin{array}{l}\text { Table } 1 . \text { Demographics and clinical characte } \\
\text { patient group. }\end{array}$} & Mean \\
\hline \multicolumn{3}{|l|}{ Age } & $\begin{array}{l}18.4 \pm 11.8 \\
\text { years }\end{array}$ \\
\hline \multicolumn{3}{|c|}{ Pretransfusion hemoglobin ( $\mathrm{g} / \mathrm{dL})$} & $8.7 \pm 0.78$ \\
\hline \multicolumn{3}{|l|}{ Serum ferritin (ng/mL) } & $1770.8 \pm 1883$ \\
\hline \multicolumn{3}{|l|}{ TSH (mIU/L) } & $2.7 \pm 1.14$ \\
\hline \multicolumn{3}{|l|}{ fT4 (pmol/L) } & $11.3 \pm 2.15$ \\
\hline & & $n$ & $\%$ \\
\hline \multirow[t]{2}{*}{ Age } & $<18$ years & 25 & 50 \\
\hline & $>18$ years & 25 & 50 \\
\hline \multirow[t]{2}{*}{ Sex } & Male & 22 & 44 \\
\hline & Female & 28 & 56 \\
\hline \multirow[t]{4}{*}{ Ferritin $(\mathrm{ng} / \mathrm{mL})$} & $<500$ & 8 & - \\
\hline & $500-1000$ & 10 & - \\
\hline & $1000-2500$ & 23 & - \\
\hline & $>2500$ & 9 & - \\
\hline \multirow[t]{3}{*}{ Chelator } & Deferasirox & 38 & 75.5 \\
\hline & Deferiprone & 8 & 16.3 \\
\hline & None & 4 & 8.2 \\
\hline \multirow[t]{2}{*}{ Splenectomy } & No & 33 & 66 \\
\hline & Yes & 17 & 34 \\
\hline \multirow[t]{2}{*}{ Osteoporosis } & Yes & 24 & 48 \\
\hline & No & 26 & 52 \\
\hline \multirow{3}{*}{$\begin{array}{l}\text { Liver iron concentration } \\
\text { (mg/g dry weight) }\end{array}$} & $<7$ & 21 & 50 \\
\hline & $7-15$ & 11 & 26 \\
\hline & $>15$ & 10 & 24 \\
\hline Non-MRI & - & 8 & - \\
\hline \multirow[t]{3}{*}{ Heart T2* (ms) } & $<10$ & 2 & 4 \\
\hline & $10-20$ & 3 & 6 \\
\hline & $>20$ & 37 & 74 \\
\hline Non-MRI & - & 8 & - \\
\hline
\end{tabular}




\begin{tabular}{|c|c|c|c|}
\hline Renal function tests & Mean \pm SD & Min - Max & Reference ranges* \\
\hline FENa & $0.65 \pm 0.32$ & $0.15-1.54$ & $<1 \%$ \\
\hline $\mathrm{Na}, \mathrm{mmol} / \mathrm{L}$ & $137.8 \pm 2.04$ & $135-142$ & $136-145$ \\
\hline $\mathrm{K}, \mathrm{mmol} / \mathrm{L}$ & $4.65 \pm 0.5$ & $3.8-5.3$ & $3.5-5.1$ \\
\hline $\mathrm{Ca}, \mathrm{mg} / \mathrm{dL}$ & $9.39 \pm 0.56$ & $8.1-10.9$ & $9.2-11$ \\
\hline $\mathrm{P}, \mathrm{mg} / \mathrm{dL}$ & $4.7 \pm 0.79$ & $3.2-6$ & $3.4-4.2$ \\
\hline $\mathrm{Mg}, \mathrm{mg} / \mathrm{dL}$ & $1.1 \pm 2.3$ & $1.1-2.3$ & $1.5-2.5$ \\
\hline $\mathrm{uCa} / \mathrm{Cr}$ & $0.22 \pm 0.11$ & $0.1-0.4$ & $<0.2$ \\
\hline Urea, mg/dL & $30.24 \pm 9.44$ & $9-45$ & $5-50$ \\
\hline $\mathrm{Cr}, \mathrm{mg} / \mathrm{dL}$ & $0.42 \pm 0.16$ & $0.2-0.79$ & $0.4-0.7$ \\
\hline Albumin, g/dL & $4.64 \pm 0.36$ & $4.1-5.3$ & $2.9-4.6$ \\
\hline $\mathrm{GFR}, \mathrm{mL} / \mathrm{min} / 1.73 \mathrm{~m}^{2}, 2-12$ years & $216 \pm 57.2$ & $90-302$ & $113 \pm 27$ \\
\hline $\mathrm{GFR}, \mathrm{mL} / \mathrm{min} / 1.73 \mathrm{~m}^{2}, 13-21$ years (female) & $213 \pm 65$ & $99-213$ & $126 \pm 22$ \\
\hline $\mathrm{GFR}, \mathrm{mL} / \mathrm{min} / 1.73 \mathrm{~m}^{2}, 13-21$ years (male) & $206 \pm 20.8$ & $110-300$ & $140 \pm 30$ \\
\hline $\mathrm{GFR}, \mathrm{mL} / \mathrm{min} / 1.73 \mathrm{~m}^{2},>21$ years & $180 \pm 55$ & $81-248$ & $70-145$ \\
\hline \multicolumn{4}{|c|}{ *Reference ranges of the Clinical Biochemistry Laboratory of the Faculty Medicine of İstanbul University. } \\
\hline
\end{tabular}

Table 3. Serum cystatin-C and urinary $\beta 2-$ microglobulin levels in the patient and control groups.

\begin{tabular}{|l|l|l|l|}
\hline & $\begin{array}{l}\text { Patient group } \\
\text { (mean } \pm \text { SD) }\end{array}$ & $\begin{array}{l}\text { Control group } \\
\text { (mean } \pm \text { SD) }\end{array}$ & p-value \\
\hline SCys-C, mg/L & $0.75 \pm 0.12$ & $0.66 \pm 0.09$ & 0.001 \\
\hline U $\beta 2 M G, \mathrm{mg} / \mathrm{L}$ & $0.35 \pm 0.43$ & $0.20 \pm 0.01$ & 0.010 \\
\hline SCys-C: Serum cystatin-C, U $\beta 2 M G$ : urinary $\beta 2$-microglobulin, SD: standard deviation. \\
\hline
\end{tabular}

the patients who were on DFX and the controls $(p=0.002)$ (Table 4). No correlations were found between DFX dosages and SCys-C concentrations. When urinary $\beta 2 \mathrm{MG}$ levels were categorized by iron chelation therapy, there were no differences between the patients who were on DFP and the controls, while significant differences were found between the patients who were on DFX and the controls $(p=0.004)$ (Table 4$)$. In the subgroup of patients on DFX, the assessment of U $\beta 2 \mathrm{MG}$ and SCys-C levels by DFX doses revealed that there were no significant differences between the controls and patients who were taking DFX at a dose of 15$20 \mathrm{mg} / \mathrm{kg}$, while statistically significant differences were found between controls and patients who were taking DFX at a dose of $20-40 \mathrm{mg} / \mathrm{kg}(\mathrm{p}=0.011)$. U $32 \mathrm{MG}$ levels were increased with increasing DFX doses. SCys-C levels were higher in all patient groups in comparison to the control group $(p=0.013)$, but the difference was not dose-related.

\section{Discussion}

In our study, serum electrolytes were within reference ranges, but FENa levels were elevated in 8 patients. In another study, FENa was elevated in 29\% of 103 TBT patients [3]. Several studies have reported normal FENa levels $[4,5]$. In our study the $\mathrm{Ca} / \mathrm{Cr}$ ratio was found to be higher than the upper limit of the normal range in 28\% of the patients. Higher $\mathrm{Ca} / \mathrm{Cr}$ ratios may be associated with tubular dysfunction as well as with impaired calcium homeostasis or bone disorders. In our study, osteoporosis was diagnosed in almost half of the patients. Some studies have reported high levels of U $\beta 2 M G$ in patients with TBT $[6,7,8]$, while other studies reported the opposite [5]. In our study, U $\beta 2 \mathrm{MG}$ concentrations in patients were significantly higher than in the controls. No significant differences were found between the controls and the subgroup of patients who were on DFP, whereas statistically significant differences were found between the controls and the DFX subgroup. Positive 


\begin{tabular}{|c|c|c|c|c|c|}
\hline & Deferiprone $(n=8)$ & Deferasirox $(n=38)$ & Controls (mean \pm SD) & p-value* & $p$-value $e^{* *}$ \\
\hline SCys-C, mg/L & $0.73 \pm 0.09$ & $0.75 \pm 0.13$ & $0.66 \pm 0.09$ & NS & 0.002 \\
\hline $\mathrm{U} \beta 2 \mathrm{MG}, \mathrm{mg} / \mathrm{L}$ & $0.20 \pm 0.01$ & $0.39 \pm 0.49$ & $0.20 \pm 0.01$ & NS & 0.004 \\
\hline
\end{tabular}

\section{Uß2MG}

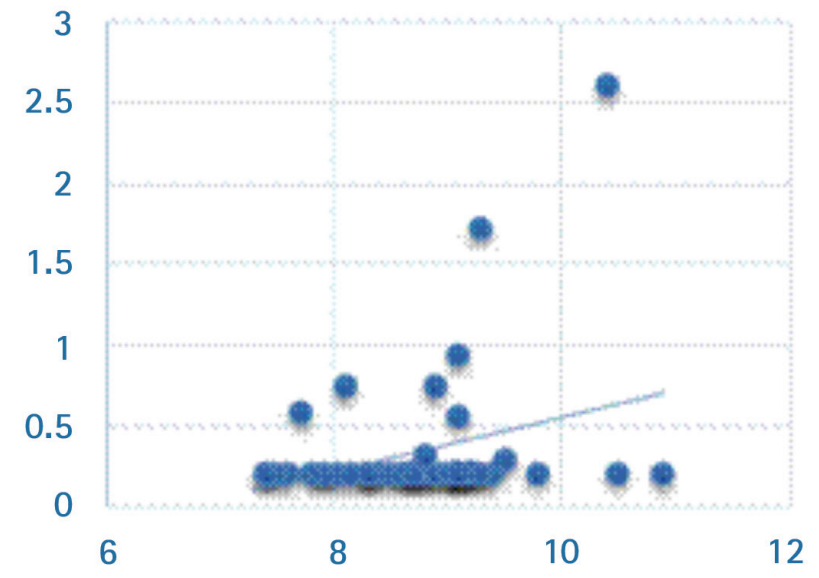

$\mathrm{Hb} \mathrm{gr} / \mathrm{dl}$

\section{SCys-C}

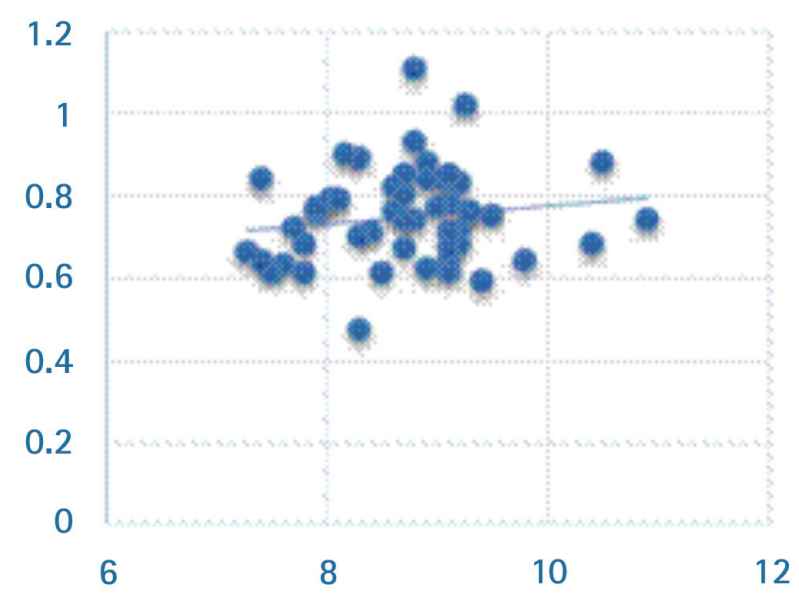

$\mathrm{Hb}$ gr/dl

Figure 1. Correlations between pretransfusion hemoglobin and urinary $\beta 2$-microglobulin and serum cystatin-C.

Uß2MG: Urinary $\beta 2-$ microglobulin, SCys-C: serum cystatin-C, $\mathrm{Hb}$ : hemoglobin.

correlations between the U $\beta 2 \mathrm{MG}$ levels and DFX doses suggested that DFX might cause dose-dependent tubulopathy. U $\beta 2 M G$ levels were significantly higher in patients than the controls, particularly in patients who had ferritin levels of $<500 \mathrm{ng} / \mathrm{mL}$ or
U $\beta 2 M G$

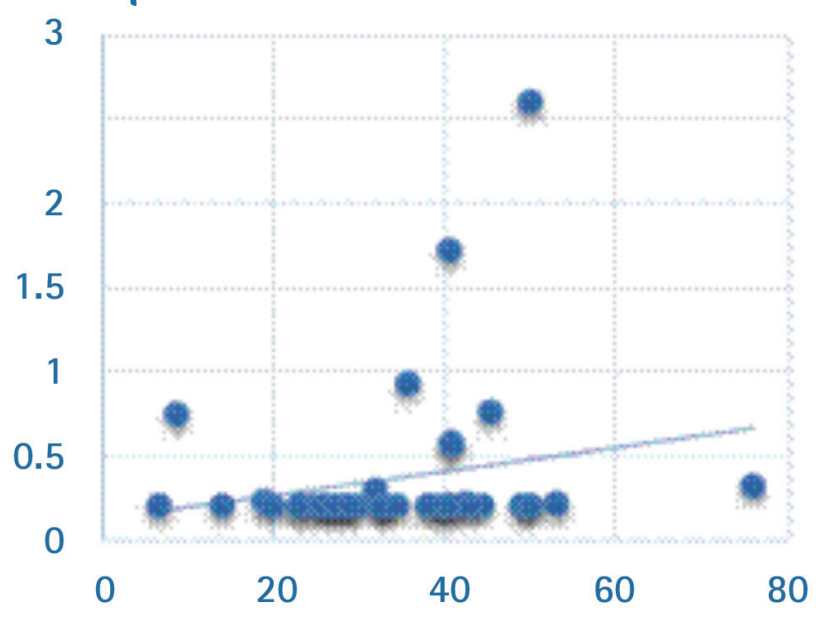

SCys-C

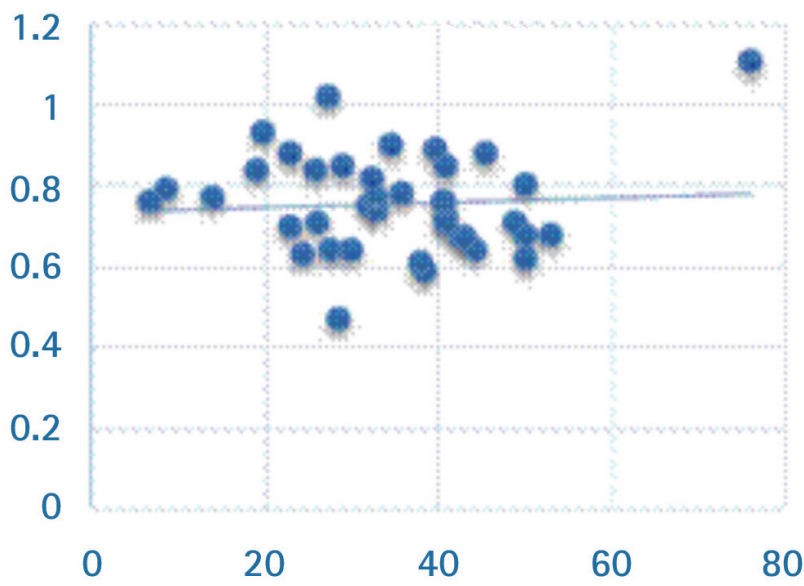

\section{Heart T2* MRI}

Figure 2. Correlations between heart $\mathrm{T} 2^{*}$ and $\mathrm{U} \beta 2 \mathrm{MG}$ and SCys-C. U $\beta 2 M G$ : Urinary $\beta 2-$ microglobulin, SCys-C: serum cystatin-C, MRI: magnetic resonance imaging.

$>1000 \mathrm{ng} / \mathrm{mL}$, whereas even though U $32 \mathrm{MG}$ levels were slightly elevated in the subgroup of patients with ferritin between 500 and $1000 \mathrm{ng} / \mathrm{mL}$, the difference between this subgroup and the control group was not statistically significant. No associations were found between U $\beta 2 M G$ levels and iron load. 
GFR has been a commonly used method to measure kidney functions. In two studies, no significant differences were found in GFR between patients and controls [3,9]. In our study, GFR in the patient group was higher than the upper limit of the age-adjusted reference range. The routine markers of kidney function, including serum urea and $\mathrm{Cr}$ levels, were within normal limits in all patients, in line with similar studies in the literature $[10,11,12]$.

Some studies reported higher SCys-C levels in patients with TBT $[13,14,15]$. In our study, SCys-C levels were found to be significantly higher in the patients in comparison to the controls. No differences were found between the patients who were taking DFP and the controls, while SCys-C levels were significantly higher in patients on DFX in comparison to the controls. No correlations were found between SCys-C or ferritin levels and pretransfusion $\mathrm{Hb}$, liver, and heart $\mathrm{T}^{*}$ values, while SCys-C levels increased with age. Koliakos et al. [16] revealed that the urinary markers of tubular dysfunctions correlated positively with serum ferritin and liver iron deposition in patients with TBT. Papassotiriou et al. [17] detected elevated SCys-C in patients who received DFX at doses of $20-40 \mathrm{mg} / \mathrm{kg} /$ day. Acute kidney injury has been reported in $40 \%$ of patients on deferoxamine [18]. None of our patients were taking deferoxamine during this study.

\section{Conclusion}

In conclusion, patients with TDT may develop renal dysfunction. In follow-up, regular testing for early markers in addition to routine kidney function tests may be beneficial to prevent future severe kidney dysfunction.

\section{Ethics}

Ethics Committee Approval: İstanbul University İstanbul Faculty of Medicine (approval number: 07.03.2014/05).

Informed Consent: Patients consent was obtained.

\section{Authorship Contributions}

Surgical and Medical Practices: Z.K., A.A.; Concept: Z.K., S.E.; Design: S.K., A.Y.; Data Collection or Processing: A.A.; Analysis or Interpretation: A.Y.; Literature Search: A.A., A.Y., S.K.; Writing: S.K., A.A., Z.K.

Conflict of Interest: The authors of this paper have no conflicts of interest, including specific financial interests, relationships, and/or affiliations relevant to the subject matter or materials included.

\section{References}

1. Steinberg MH, Forget, BG, Higgs DR, Weatherall DJ. Disorders of Hemoglobin: Genetics, Pathophysiology, Clinical Management. $2^{\text {nd }}$ ed. Cambridge, Cambridge University Press, 2009.

2. Musallam KM, Capellini MD, Taher AT. Iron overload in $\beta$-thalassemia intermedia: an emerging concern. Curr Opin Hematol 2013;20:187-192.

3. Mohkam M, Shamsian BS, Gharib A, Nariman S, Arzanian MT. Early markers of renal dysfunction in patients with beta-thalassemia major. Pediatr Nephrol 2008;23:971-976.

4. Aldudak B, Karabay Bayazit A, Noyan A, Ozel A, Anarat A, Sasmaz I, Kilinç Y, Gali E, Anarat R, Dikmen N. Renal function in pediatric patients with betathalassemia major. Pediatr Nephrol 2000;15:109-112.

5. Jafari HM, Vahidshahi K, Kosaryan M, Karami H, Mandavi MR. Ehteshami S. Major beta-thalassemia, use of desferiexamine and renal proximal tubular damage. Bratisl Lek Listy 2011;112:278-281.

6. Sadeghi-Bojd $\mathrm{S}$, Hashemi M, Karimi M. Renal tubular function in patients with beta-thalassaemia major in Zahedan, southeast Iran. Singapore Med J 2008;49:410-412.

7. Mula-Abed WA, Al-Hashmi HS, Al-Muslahi MN. Indicators of renal glomerular and tubular functions in patients with beta-thalassaemia major: A cross sectional study at the Royal Hospital, Oman. Sultan Qaboos Univ Med J 2011;11:69-76.

8. Deveci B, Kurtoglu A, Kurtoglu E, Salim O, Toptas T. Documentation of renal glomerular and tubular impairment and glomerular hyperfiltration in multitransfused patients with beta thalassemia. Ann Hematol 2016;95:375381.

9. Kalman $S$, Atay AA, Sakallioglu O, Ozgürtaş T, Gök F, Kurt I, Kürekçi AE, Ozcan 0 , Gökçay $E$. Renal tubular function in children with beta-thalassemia minor. Nephrology (Carlton) 2005;10:427-429.

10. Smolkin V, Halevy R, Levin C, Mines M, Sakran W, Ilia K, Koren A. Renal function in children with beta-thalassemia major and thalassemia intermedia. Pediatr Nephrol 2008;23:1847-1851.

11. Lai $M E$, Spiga $A$, Vacquer $S$, Carta MP, Corrias $C$, Ponticelli C. Renal function in patients with $\beta$-thalassaemia major: a long-term follow-up study. Nephrol Dial Transplant 2012;27:3547-3551.

12. Almadzadeh A, Jalali A, Assar S, Khalilian H, Zandian K, Pedram M. Renal tubular dysfunction in pediatric patients with beta-thalassemia major. Saudi J Kid Dis Transpl 2011;22:497-450.

13. Economou M, Printza N, Teli A, Tzimouli V, Tsatra I, Papachristou F, Athanassiou-Metaxa M. Renal dysfunction in patients with beta-thalassemia major receiving iron chelation therapy either with deferoxamine and deferiprone or with deferasirox. Acta Haematol 2010;123:148-152.

14. Ali BA, Mahmoud AM. Frequency of glomerular dysfunction in children with beta thalassaemia major. Sultan Qaboos Univ Med J 2014;14:88-94.

15. Hamed AE, Elmelegy NT. Renal functions in pediatric patients with betathalassemia major: relation to chelation therapy: original prospective study. Ital J Pediatr 2010;30:36-39.

16. Koliakos G, Papachristou F, Koussi A, Perifanis V, Tsatra I, Souliou E, Athanasiou M. Urine biochemical markers of early renal dysfunction are associated with iron overload in beta-thalassaemia. Clin Lab Haematol 2003;25:105-109.

17. Papassotiriou I, Margeli A, Hantzi E, Delaporta P, Sergounioti A, Goussetis E, Ladis V, Kattamis A. Cystatin C levels in patients with beta-thalassemia during deferasirox treatment. Blood Cells Mol Dis 2010;44;152-155.

18. Prasannan L, Flynn JT, Levine JE. Acute renal failure following deferoxamine overdose. Pedi-atr Nephrol 2003;18:283-285. 